Vives, A., Rubilar, T., Herrero-Pérezrul, M.D., \& Ceballos-Vázquez, B.P. (2021). Reproduction of the sea urchin Tripneustes depressus (Camarodonta: Toxopneustidae) in Bahía de La Paz, Baja California Sur, Mexico. Revista de Biología Tropical, 69(S1), 202-218. DOI 10.15517/rbt.v69iSuppl.1.46353

DOI 10.15517/rbt.v69iSuppl.1.46353

\title{
Reproduction of the sea urchin Tripneustes depressus (Camarodonta: Toxopneustidae) in Bahía de La Paz, Baja California Sur, Mexico
}

\author{
Ailet Vives ${ }^{1}$ \\ Tamara Rubilar ${ }^{2,3}$ \\ María Dinorah Herrero-Pérezrul ${ }^{1}$ \\ Bertha Patricia Ceballos-Vázquez ${ }^{1 *}$
}

1. Instituto Politécnico Nacional, Centro Interdisciplinario de Ciencias Marinas, Av. Instituto Politécnico Nacional s/n, Playa Palo de Santa Rita, La Paz, Baja California Sur, México; ailetvives@gmail.com, dherrero@ipn.mx, bceballo@ipn.mx (*Correspondence).

2. Laboratorio de Química de Organismos Marinos, Instituto Patagónico del Mar. Facultad de Ciencias Naturales y Ciencias de la Salud. Universidad Nacional de la Patagonia San Juan Bosco. Bvld. Brown, Puerto Madryn, Chubut, Argentina; tamararubilar@gmail.com

3. Laboratorio de Oceanografía Biológica, Centro para el Estudio de Sistemas Marinos. Bvld. Brown, Puerto Madryn, Argentina; tamararubilar@gmail.com

Received 30-VI-2020. Corrected 25-X-2020. Accepted 06-XI-2020.

\begin{abstract}
Introduction: Sea urchin gonads (roe or uni) are considered a culinary delicacy worldwide. However, only a few species are considered edible and commercialized. The sea urchin Tripneustes depressus has generated the interest of producers in Baja California Sur, Mexico, due to the quality of its gonads. A biological basis for designing a management strategy is key to consider its commercial exploitation. Objective: To determine the reproductive season of $T$. depressus through description of the gonad stages and reproductive cycle, and to establish its relationship with environmental factors. Methods: We collected monthly samples (October 2016-September 2017), recording in-situ temperature and photoperiod. We evaluated a sample of 1055 specimens for demographic characteristics, using total weight $(\mathrm{g})$ and test diameter $(\mathrm{cm})$. We also did a histological analysis of gonads from 178 individuals. Results: Average test diameter was $9.70 \pm 0.03 \mathrm{~cm}(5-12.50 \mathrm{~cm})$. Based on the proportion into the gonad of sexual (gametes) and somatic (nutritive phagocytes) cells, we propose five gonad stages (growing, premature, mature, spawning, and intergametic) for both sexes. There were two times of the year when gonads were heaviest and closely corresponded to the growing stage, coinciding with the highest proportions of nutritive phagocytes. Gonad development (growing and premature stages) peaks in the months with the longest daylight periods, with spawning in the shortest daylight periods. Conclusions: Gonad wet weight and adjusted gonad weight are good indicators of the reproductive season of T. depressus. The lowest gonad wet weights were matched the spawning peak in the shortest daylight period (January and March).
\end{abstract}

Key words: reproductive season; adjusted gonad weights; gonadal stages; urchin roe; Echinoidea.

Sea urchins are ecologically important due to their major impact on community structure and dynamics in shallow subtidal zones (Harrold \& Pearse, 1987; Toro-Farmer, Cantera, Londono-Cruz, Orozco, \& Neira, 2004). In addition, their gonads are consumed as food, making of sea urchins a valuable fishery resource (Montealegre \& Gómez, 2005; Lawrence, 2007).

Knowledge about the reproductive cycle of sea urchins is key for understanding their life history. Sea urchin gonads contain not only 
reproductive cells, but also nutritive phagocytes, thus serving also as nutrient storage organs (Walker, 1982; Unuma, 2002; Walker, Lesser, \& Unuma, 2013; Unuma, Murata, Hasegawa, Sawaguchi, \& Takahashi, 2015). This makes the gametogenic cycle more complex; the cycle begins with fully developed nutritive phagocytes and changes in the epithelium and germ cells, which differentiate into male and female gametes that then ripe until being released along with the decrease of nutritive phagocytes (Walker, Unuma, \& Lesser, 2007), showing an alternating abundance of the somatic and reproductive cell types. Besides, factors such as temperature, photoperiod, hydrodynamics, food availability, and diet composition influence the reproductive cycle and development of echinoids (Ridder \& Lawrence, 1982; McBride, Pinnix, Lawrence, Lawrence, \& Mulligan, 1997; Fernandez \& Pergent, 1998; Spirlet, Grosjean, \& Jangoux, 2000; Vaitilingon, Rasolofonirina, \& Jangoux, 2005; Lawrence, 2007).

Currently, only two sea urchin species are commercially exploited in Mexico, Mesocentrotus franciscanus (=Strongylocentrotus franciscanus) (red sea urchin) and Strongylocentrotus purpuratus (Pacific purple sea urchin), both restricted to Baja California. In Baja California Sur, Tripneustes depressus is one of the most common sea urchins and along with its large size and the fact that its gonads have been recently rated as of good quality (Vives, 2018), generating the interest of local fishing cooperatives to market it. However, it is necessary at least to generate biological information and made an appropriate population analysis base and a management strategy before thinking about the commercial exploitation of $T$. depressus, in fact it would be more appropriate to think about developing its aquaculture. In this sense, the objective of our study is to generate biological knowledge of $T$. depressus determining its reproductive season through description of the gonad stages and the reproductive cycle, besides establish its relationship with environmental factors, and to provide information on some demographic characteristics in a natural population from the southwestern part of Bahía de la Paz.

\section{MATERIALS AND METHODS}

Specimen collection: Monthly samplings were carried out from October 2016 to September 2017 at El Tecolote beach (Fig. 1), in the southwestern part of Bahía de la Paz, Baja California Sur State, Mexico (2420'9” N \& $\left.110^{\circ} 13^{\prime} 48^{\prime \prime} \mathrm{W}\right)$. Samples were collected at 1-5 $\mathrm{m}$ depth, according to the known distribution of $T$. depressus in the study area. Temperature $\left({ }^{\circ} \mathrm{C}\right)$ was measured in situ at the time of collection with a mercury thermometer; photoperiod data for the study period were obtained from Timeanddate (2017).

Sample processing: To evaluate demographic characteristics based on average test diameter and total body weight, between 80 and 100 specimens from all size classes (5-12.5 $\mathrm{cm}$ in test diameter) found in each monthly sample were measured with a vernier caliper and weighed with a digital scale, to the nearest $1 \mathrm{~mm}$ or $0.01 \mathrm{~g}$, respectively.

To characterize the reproductive cycle, 15 specimens were randomly selected from each monthly sample, except in January and December; their gonads were excised and weighed (to the nearest $0.0001 \mathrm{~g}$ ), fixed in Finefix for 48 hours, and preserved in $70 \%$ alcohol. Gonads were subsequently processed using conventional histological techniques and $5 \mu \mathrm{m}$-thick sections were cut and stained with haematoxylin-eosin (Humason, 1979). From the histological analysis, specimens were first sexed, since these did not show any apparent differences either in external morphology or gonad color to determine sex macroscopically. Afterward, gonad stages were identified based on the proportion of sexual cells (gametes) and somatic phagocytic cells (nutritive phagocytes), using the scale proposed by Unuma et al. (2015) modified for this species. Five stages were considered: growing, premature, mature, spawning, and intergametic. Histograms of the monthly frequency of the different gonad 


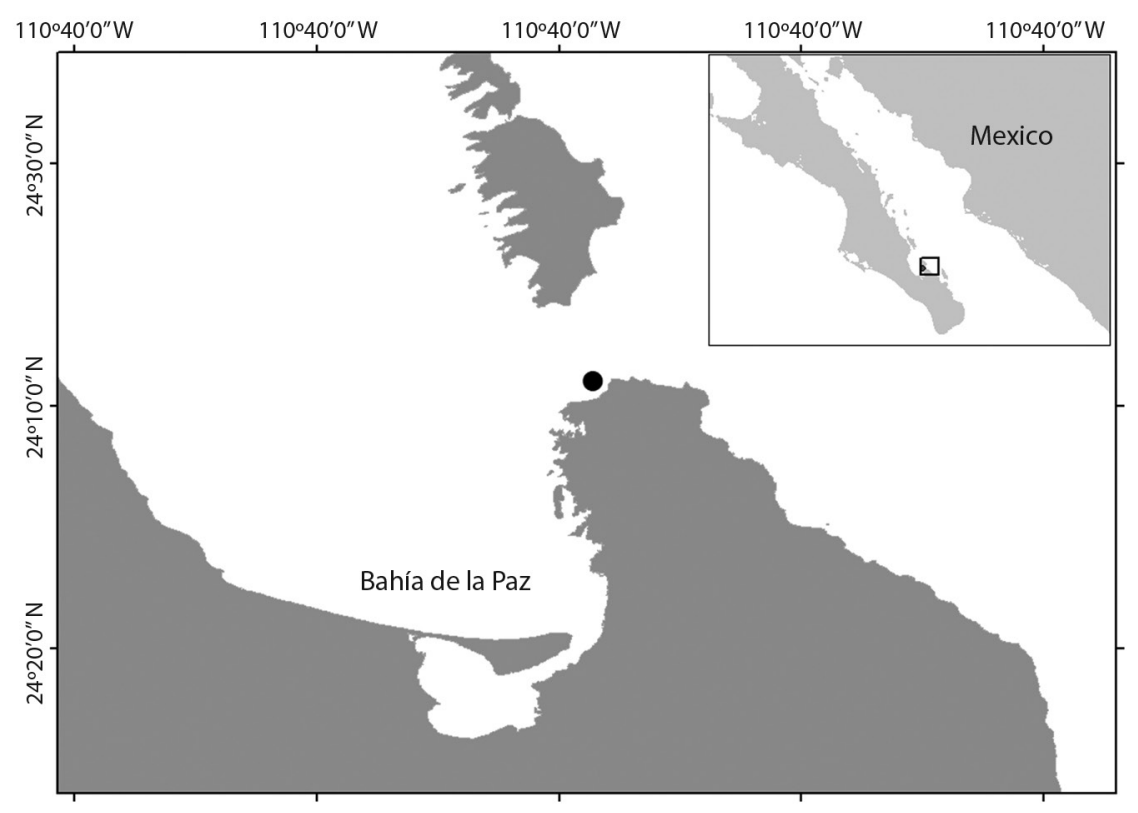

Fig. 1. Location of the study area in Bahía de la Paz, Baja California Sur State, Mexico.

stages were plotted to identify the reproductive cycle of this species.

The test diameter (D) and total body weight (W) of specimens were used to calculate a condition index $(\mathrm{CI})$ using the following formula: $C I=W^{*} 100 / D^{b}$. The gonad index (GI) of each specimen was calculated as the percentage ratio of gonad wet weight to total body weight (Meidel \& Scheibling, 1998); these values were used to assess the potential use of the index as an indicator of reproductive activity in this species (Sánchez-España, Martínez-Pita, \& García, 2004). Additionally, due to the proven allometric relationship between gonad wet weight and test diameter in sea urchins (Ebert, Hernandez, \& Russell, 2011), a temporal pattern of the gonad cycle was evaluated testing the average gonad wet weight $(\mathrm{AGW})$ as described below.

Statistical analyses: A temporal pattern of the gonad cycle was evaluated by using a GLM two-way ANCOVA, with test diameter as the covariate and sex and months as factors; with this, it was possible to determine (eliminating the effect of the body size), whether regressions of the average gonad wet weight (AGW) for each individual test diameter differed between months and sexes (Packard \& Boardman, 1999). Since our data did not follow a normal distribution (Sokal \& Rohlf, 1995), non-parametric tests were used for the analyses. The KruskalWallis method was used to test for differences between sexes and between reproductive stages in each of the variables examined. The Spearman's rank correlation coefficient was used to examine the correlation between test diameter and total body weight, and between gonad wet weights and the environmental variables. All the analyses were carried out using the software Statistica v.8.0; a significance level $\alpha=$ 0.05 was used for all tests.

\section{RESULTS}

Demographic characteristics: The results from the 1055 specimens sampled showed that total body weight ranged from 72 to $912 \mathrm{~g}$, with a mean ( \pm standard error) of $411.72 \pm 4.25$ $\mathrm{g}$, median of $422 \mathrm{~g}$, and mode of $445 \mathrm{~g}$; $60 \%$ of specimens weighed between 318 and 516 

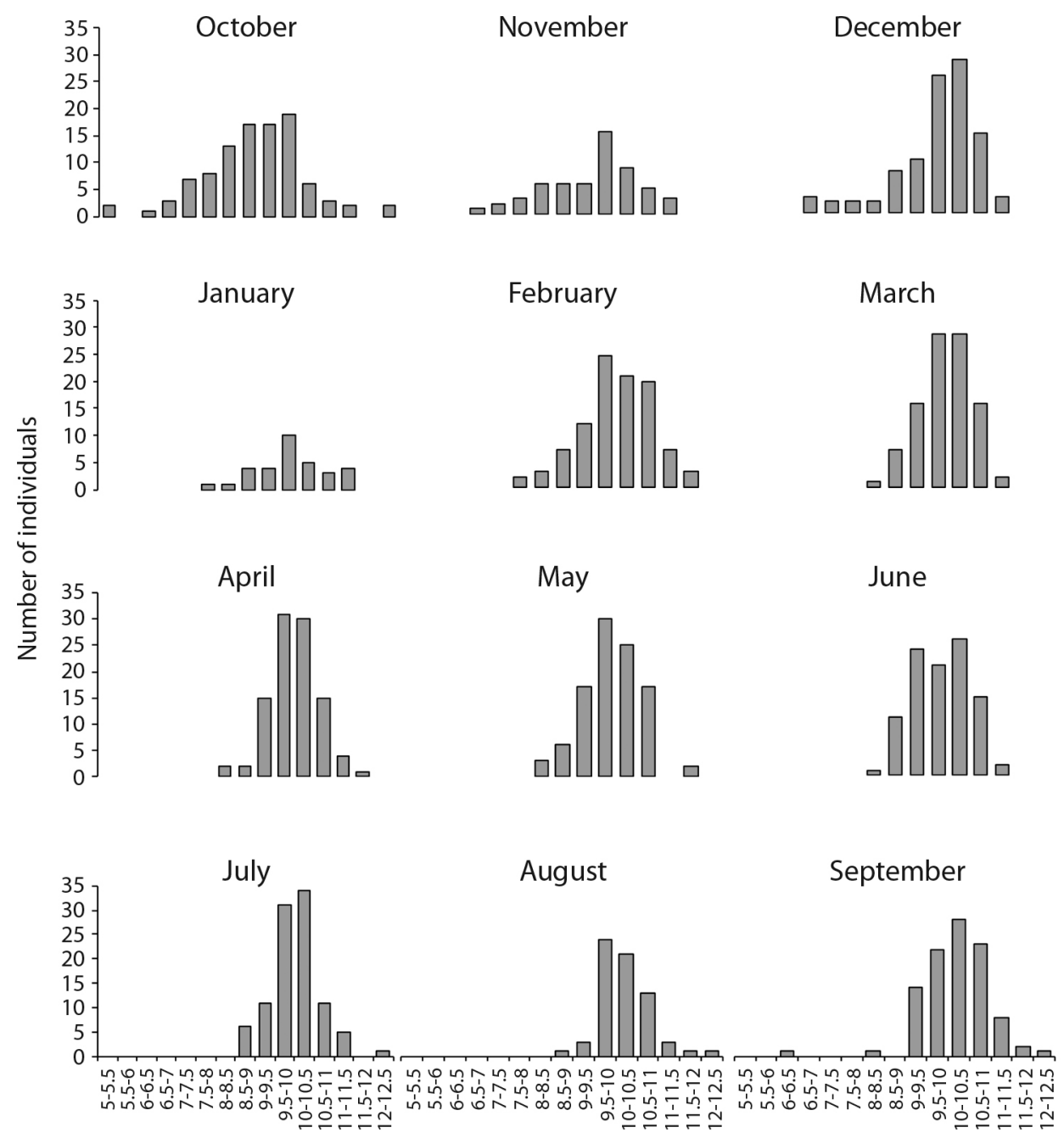

Test diameter $(\mathrm{cm})$

Fig. 2. Monthly frequency distributions of test diameter (cm) of Tripneustes depressus in Bahía de La Paz, BCS, Mexico ( $\mathrm{N}=1055)$.

g. There were significant differences between months (KW: $\mathrm{H}=317.24, \mathrm{P}<0.0001$ ) in total body weight; the lightest specimens were recorded in October and December and the heaviest from April to September.

Test diameter ranged between 5 and 12.50 $\mathrm{cm}$, with a mean ( \pm standard error) of $9.79 \pm$ $0.03 \mathrm{~cm}$. Most specimens (52\%) had a test diameter between 9 and $11 \mathrm{~cm}$. The monthly frequency distributions of test diameter were unimodal (Fig. 2); the smallest specimens were recorded from October to December.

A significant correlation $(\mathrm{rs}=0.27$, $\mathrm{P}<0.05)$ between test diameter and total weight was detected. There were significantly more females than males $(0.7 \mathrm{M}: 1.4 \mathrm{~F})$ in the 178 specimen sample that was sexed $(\chi 2=5.75$, $\mathrm{P}<0.05)$. We found no significant differences between males and females in test diameter, total body weight, or CI ( $\mathrm{P}>0.05)$, Table 1 . 
Gonad description: The sea urchin T. depressus, has five lobe-shaped gonads attached internally to the test. Each gonad lobe has an elongated shape pointed towards the oral end and rounded towards the aboral end; granular appearance that resembles a bunch of grapes; color ranging from yellowish to brownish; texture varying from flaccid to turgid.

\section{Gonad female stages:}

Growing stage: Higher proportion of nutritive phagocytes than germ cells. The acini showed previtellogenic oocytes towards the periphery, while the rest of the acinus was filled with nutritive phagocytes (Fig. 3A).

Premature stage: Pre-vitellogenic and vitellogenic oocytes were present at the

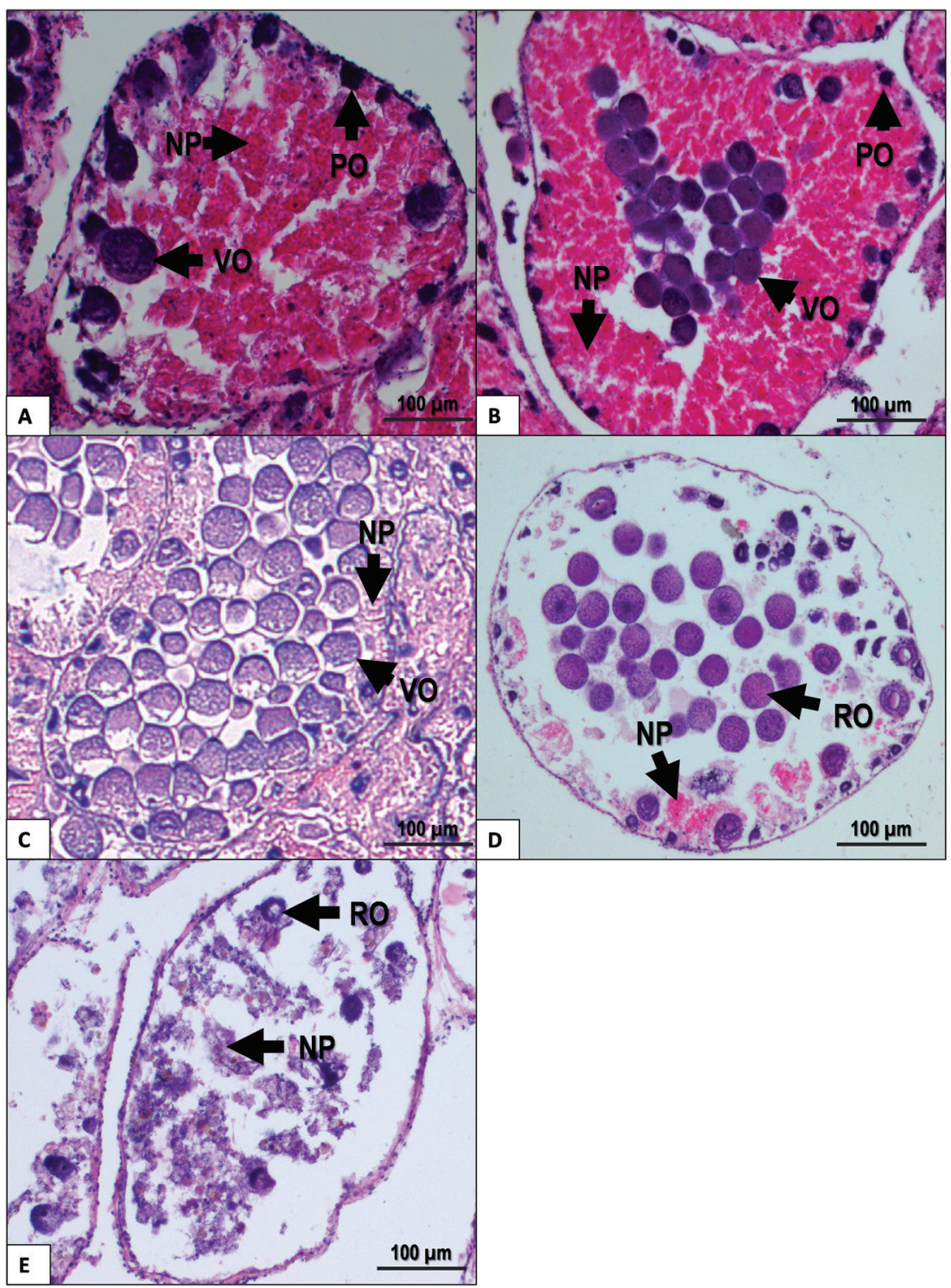

Fig. 3. Gonad female stages of T. depressus from Bahía de La Paz, BCS, Mexico: A. Growing stage. B. Premature stage. C. Mature stage. D. Spawning stage. E. Intergametic stage. NP: nutritive phagocytes. PO: previtellogenic oocytes. RO: residual oocytes. VO: vitellogenic oocytes. Scale bar $=100 \mu \mathrm{m}$. 
periphery of the acinus. Vitellogenic oocytes started to appear within the acinus. Nutritive phagocytes were still abundant, but some empty spaces could be found (Fig. 3B).

Mature stage: Higher proportion of germ cells than nutritive phagocytes. Vitellogenic oocytes filled the center of the acinus, whereas previtellogenic oocytes, when present, were found in small amounts at the periphery. Nutritive phagocytes were restricted to the periphery of acini (Fig. 3C).

Spawning stage: Nutritive phagocytes make a smaller proportion and with no nutritional content. Partially empty acini may show residual vitellogenic oocytes (Fig. 3D).

Intergametic stage: This stage represents the recovery period before the next gametogenic development. Acini are almost empty, showing nutritive phagocytes and residual oocytes undergoing resorption (Fig. 3E).

\section{Gonad male stages:}

Growing stage: Nutritive phagocytes occurred in higher proportion than germ cells. Spermatocytes and spermatogonia restricted to the periphery of the acinus. Nutritive phagocytes filled the rest of the acinus (Fig. 4A).

Premature stage: Active spermatogenesis was observed at the periphery of the acinus; spermatozoa started accumulating at the center of the acinus. Nutritive phagocytes remain abundant, but some empty spaces appear (Fig. 4B).

Mature stage: Spermatogenic cells were evident in higher proportion than nutritive phagocytes. Spermatozoa almost fill the acinus. Spermatogenic development centers can be found at the periphery of the acinus. Nutritive phagocytes occurred in low proportion, restricted to the periphery of the acinus (Fig. 4C).

Spawning: Nutritive phagocytes occurred in a small proportion and empty of nutritional content. Partially empty acini contained different quantities of spermatozoa in the lumen (Fig. 4D).

Intergametic stage: This stage represents the recovery period, prior to the onset of gametogenic development. The acini mainly contain nutritive phagocytes. Residual spermatozoa inside the acinus are undergoing resorption (Fig. 4E).

Reproductive cycle: Fig. 5A shows the frequency distribution of the gonad development stages of both sexes combined over the study period. The growing and intergametic stages occurred for most of the year and corresponded to stages of reproductive inactivity and recovery. Gamete development and growth in this species seem to take place in two seasons. The main season starts between April and August and peaks in June; the second and shorter season takes place from September to December, peaking in October. Spawning takes place between January and March, with a small secondary event in August. The gonads enter an intergametic stage after spawning and prior to starting a new cycle; this stage was most frequently seen from January to April.

Gonad weight and Gonad index: Both, gonad wet weight (GWW) and adjusted gonad weight (AGW) presented similar results (Table 1). Both values were significantly higher in males than females (KW: $\mathrm{H}=11.779, \mathrm{P}=$ 0.0006; GLM: $\mathrm{F}=39.97, \mathrm{P}<0.0001)$. Monthly variations of GWW and AGW followed a similar trend in both, males and females and also displayed a similar seasonal variation (Fig. 5C, 5D) with significant different values among months (KW: $\mathrm{H}=122.22, \mathrm{P}<0.0001$; GLM: $\mathrm{F}$ $=47.73, \mathrm{P}<0.0001)$. In the same sense, males showed gonad index values significantly higher than females (KW: $\mathrm{H}=14.274, \mathrm{P}=0.0002$ ). The highest GI values were recorded in October and December 2016, with high values also recorded between May and September 2017; the lowest values occurred from January to March 2017 (Fig. 5B). The heaviest gonads (both GWW and AGW) were found in two periods, October-December 2016 and MaySeptember 2017, and the lightest, from January to March 2017 (Fig. 5C, 5D). However, monthly variations followed a similar trend in the two sexes. 


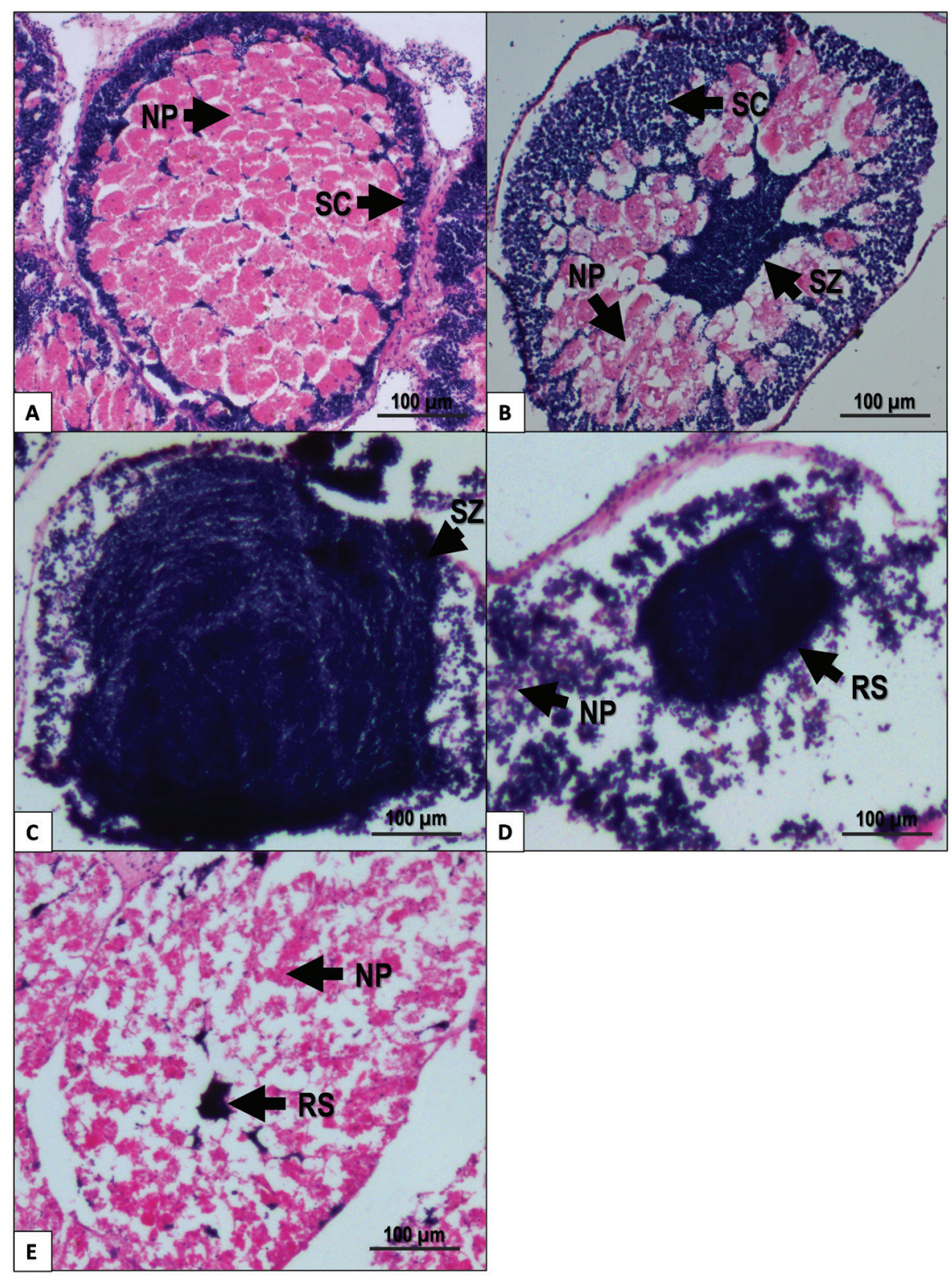

Fig. 4. Gonad male stages of $T$. depressus from Bahía de La Paz, BCS, Mexico: A. Growing stage. B. Premature stage. C. Mature stage. D. Spawning stage. E. Intergametic stage. NP: nutritive phagocytes. RS: residual spermatozoa. SC: spermatocyte. SZ: spermatozoa. Scale bar $=100 \mu \mathrm{m}$.

Environmental variables: Temperature ranged from $17^{\circ} \mathrm{C}$ (January) to $30^{\circ} \mathrm{C}$ (October) over the study period (Fig. 6A). The number of daylight hours ranged between 10 and $13 \mathrm{~h}$ per day, with the lowest values recorded from
November to January and the largest from May to August (Fig. 6B). Gonad index values were significantly correlated with temperature ( $\mathrm{rs}=$ $0.68, \mathrm{P}<0.05$ ) but not with photoperiod ( $\mathrm{rs}=$ $0.17, \mathrm{P}>0.05$ ). In contrast, gonad wet weight 

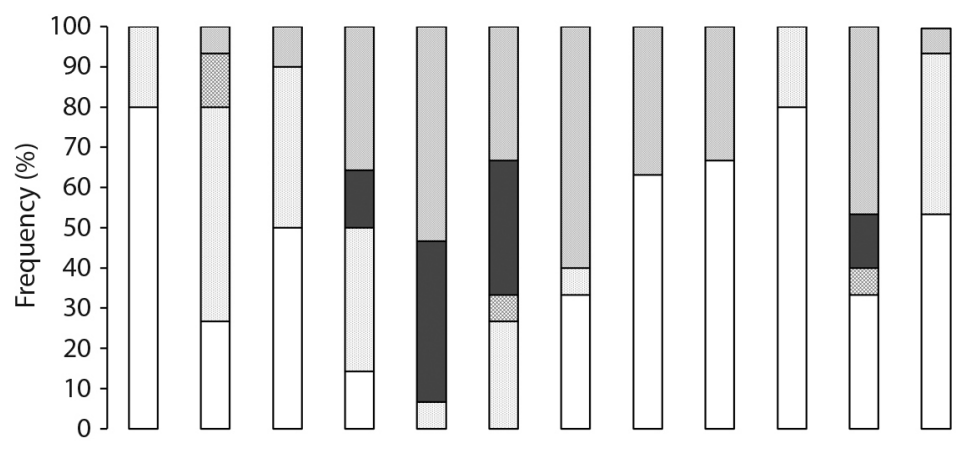

A
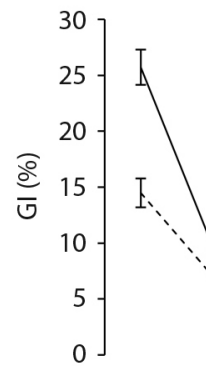

B

ㅁntergametic

- Spawning

Maturity

口Prematurity

口Growth
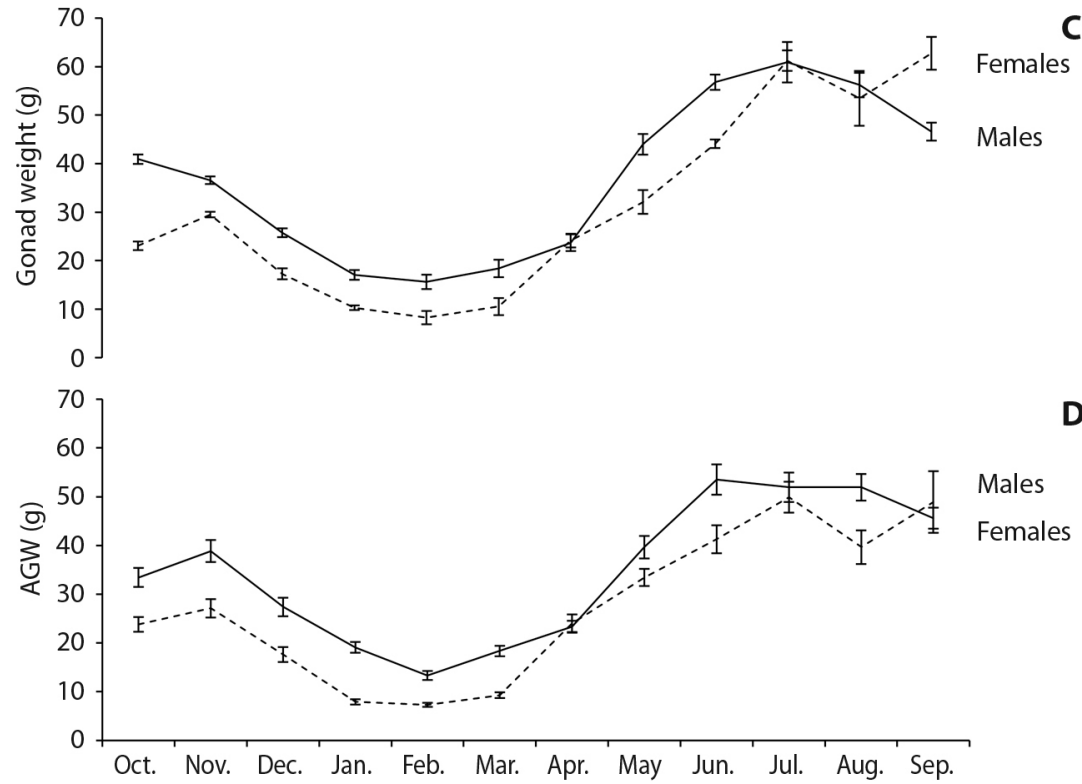

Fig. 5. A. Reproductive cycle of Tripneustes depressus as shown by the monthly frequency of gonad stages. B. Gonad index. C. Gonad wet weight. D. Adjusted gonad weight. Vertical bars are the standard errors.

was significantly correlated with photoperiod ( $\mathrm{rs}=0.41, \mathrm{P}>0.05$ ) but not with temperature ( $\mathrm{rs}=0.76, \mathrm{P}<0.05)$.

Gonad wet weight and GI were the only morphometric variables that showed statistically significant $(\mathrm{P}<0.05)$ differences between some gonad stages; in particular, values between the growing stage and the premature, spawning, and intergametic stages (Table 2). 
TABLE 1

Statistics (mean \pm standard error, range in parentheses) of the morphometric variables recorded, per sex and for the total sample for Tripneustes depressus in Bahía de la Paz, Mexico

\begin{tabular}{|c|c|c|c|c|c|}
\hline \multirow{2}{*}{ Variable } & \multirow{2}{*}{$\begin{array}{c}\text { Total } \\
\mathrm{N}=1055\end{array}$} & \multirow{2}{*}{$\begin{array}{c}\text { Females } \\
\mathrm{N}=73\end{array}$} & \multirow{2}{*}{$\begin{array}{c}\text { Males } \\
\mathrm{N}=105\end{array}$} & \multicolumn{2}{|c|}{ Kruskal-Wallis } \\
\hline & & & & $\mathrm{H}$ & $\mathrm{P}$ \\
\hline Total weight (g) & $411.72 \pm 4.25(72-912)$ & $425.04 \pm 17.73$ & $404.04 \pm 14.56$ & 2.20 & 0.138 \\
\hline Test diameter $(\mathrm{cm})$ & $9.79 \pm 0.03(5.0-12.3)$ & $9.96 \pm 0.10$ & $9.82 \pm 0.09$ & 2.36 & 0.1245 \\
\hline Condition index (\%) & $44.38 \pm 0.52(8.79-150.88)$ & $41.52 \pm 1.24$ & $41.33 \pm 1.04$ & 1.19 & 0.2745 \\
\hline Gonad wet weight (g) & & $28.65 \pm 2.33$ & $38.51 \pm 1.85$ & 11.78 & $0.0006^{*}$ \\
\hline \multirow[t]{3}{*}{ Gonad index (\%) } & & $7.45 \pm 0.61$ & $10.66 \pm 0.66$ & 14.27 & $0.0002 *$ \\
\hline & & & & \multicolumn{2}{|c|}{ GLM } \\
\hline & & & & $\mathrm{F}$ & $\mathrm{P}$ \\
\hline Adjusted gonad weight (g) & & $27.53 \pm 4.31$ & $34.70 \pm 3.96$ & 39.97 & $0.0001 *$ \\
\hline
\end{tabular}

*Variables with significant differences between females and males.

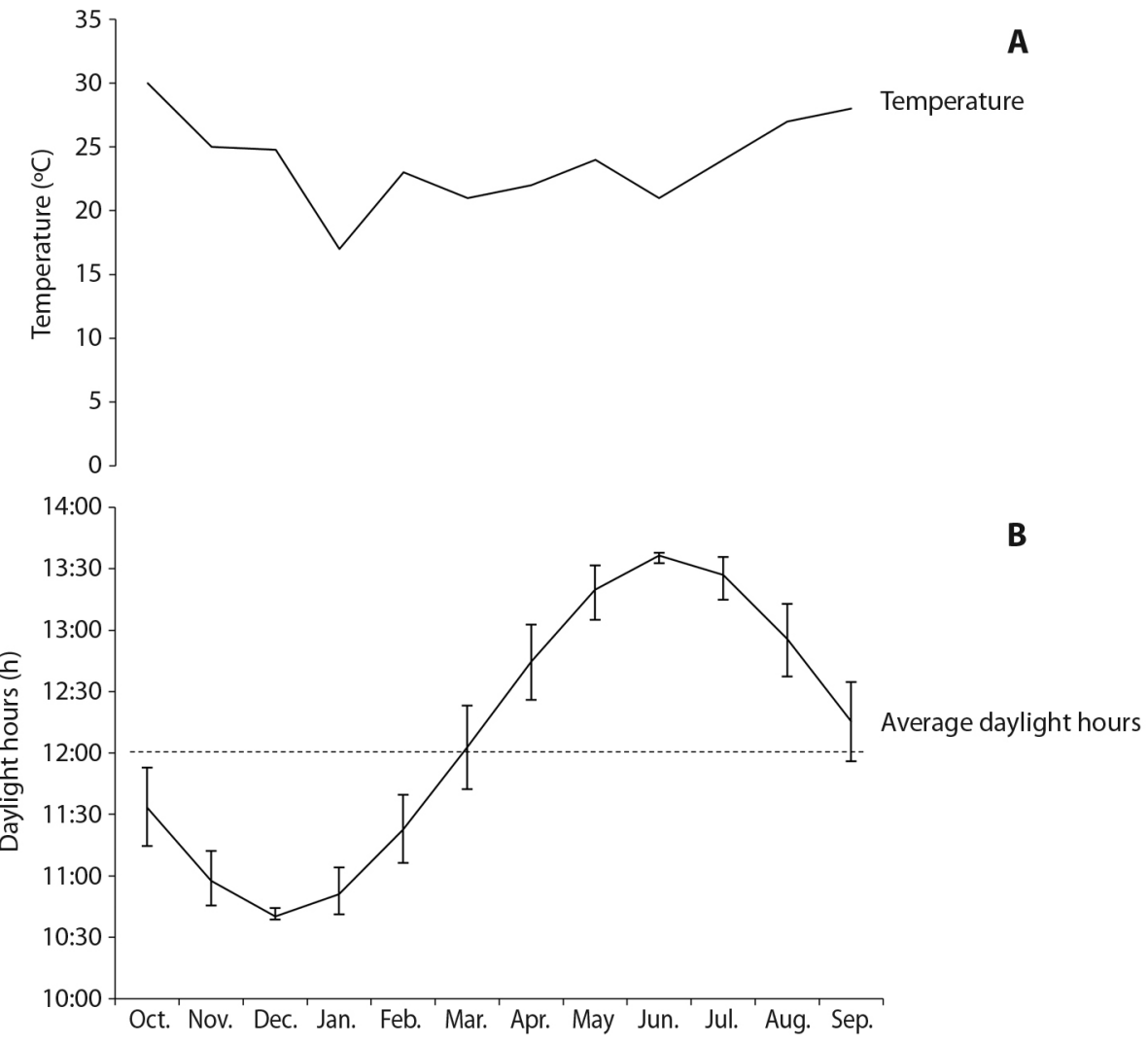

Fig. 6. Variation of environmental variables over the study period at Bahía de La Paz, BCS. A. In-situ temperature. B. Daylight hours per day; vertical bars denote the monthly range of daylight hours, the dashed line marks the $12 \mathrm{~h}$ daylight photoperiod that would be expected at the equator. 
TABLE 2

Means ( \pm standard error) of the morphometric variables recorded, per sex and gonad stage. Values with different letters are significantly different $(\mathrm{P}<0.05)$

\begin{tabular}{|c|c|c|c|c|c|c|c|}
\hline \multirow{2}{*}{ Variable } & \multicolumn{5}{|c|}{ Gonad stages } & \multicolumn{2}{|c|}{ Kruskal-Wallis } \\
\hline & Growing & Premature & Mature & Spawning & Intergametic & $\mathrm{H}$ & $\mathrm{P}$ \\
\hline \multicolumn{8}{|c|}{ Total weight, $\mathrm{g}$} \\
\hline Female & $399.14 \pm 32.2$ & $344.94 \pm 81.5$ & $551.70 \pm 95.0$ & $452.16 \pm 39.9$ & $450.57 \pm 21.0$ & 3.85 & 0.4269 \\
\hline Male & $404.81 \pm 24.0$ & $365.63 \pm 32.8$ & $428.0^{*}$ & $439.43 \pm 24.8$ & $438.95 \pm 18.2$ & 4.41 & 0.2208 \\
\hline \multicolumn{8}{|c|}{ Test diameter, cm } \\
\hline Female & $9.88 \pm 0.2$ & $9.56 \pm 0.4$ & $10.80 \pm 0.7$ & $9.90 \pm 0.3$ & $10.08 \pm 0.1$ & 3.38 & 0.4957 \\
\hline Male & $9.98 \pm 0.1$ & $9.41 \pm 0.2$ & $10.3^{*}$ & $9.96 \pm 0.3$ & $9.95 \pm 0.1$ & 4.91 & 0.1776 \\
\hline \multicolumn{8}{|c|}{ Condition Index, \% } \\
\hline Female & $39.70 \pm 2.6$ & $35.62 \pm 5.1$ & $42.90 \pm 0.3$ & $45.83 \pm 1.2$ & $43.51 \pm 1.3$ & 1.74 & 0.7840 \\
\hline Male & $39.80 \pm 1.8$ & $40.98 \pm 2.4$ & $39.2 *$ & $44.69 \pm 2.0$ & $44.05 \pm 0.5$ & 0.71 & 0.8712 \\
\hline \multicolumn{8}{|c|}{ Gonad wet weight, g } \\
\hline Female & $38.51 \pm 3.3 \mathrm{c}$ & $29.53 \pm 8.1 b c$ & $51.12 \pm 14.5 \mathrm{c}$ & $11.69 \pm 4.4 \mathrm{ab}$ & $20.74 \pm 3.2 \mathrm{a}$ & 24.28 & 0.0001 \\
\hline Male & $46.22 \pm 2.3 b$ & $29.60 \pm 3.6 \mathrm{a}$ & $15.0^{*}$ & $22.93 \pm 3.8 \mathrm{a}$ & $39.39 \pm 4.2 \mathrm{ab}$ & 20.15 & 0.0002 \\
\hline \multicolumn{8}{|c|}{ Gonad index (\%) } \\
\hline Female & $10.52 \pm 0.8 \mathrm{c}$ & $10.12 \pm 2.8 b c$ & $9.00 \pm 1.8 b c$ & $2.60 \pm 0.8 \mathrm{a}$ & $4.83 \pm 0.7 \mathrm{ab}$ & 33.14 & 0.0001 \\
\hline Male & $13.25 \pm 1.1 \mathrm{~b}$ & $9.22 \pm 1.3 \mathrm{a}$ & $3.5^{*}$ & $5.45 \pm 1.1 \mathrm{a}$ & $8.95 \pm 0.9 \mathrm{a}$ & 20.83 & 0.0001 \\
\hline
\end{tabular}

* This stage was not included in the analyses because only one mature male was found.

\section{DISCUSSION}

The specimens examined in our study were adult, mostly intermediate-sized $(9-11 \mathrm{~cm}$ in diameter) individuals. Large specimens were highly abundant in our sample, while small individuals $(<5 \mathrm{~cm})$ were absent. The absence of juveniles may be due to various causes, including predation, variability in the availability of food and refuge (Ebert, 1967; Sala \& Zabala, 1996), a different distribution than that of adults (Fernandez, Caltagirone, \& Johnson, 2001; Tomas, Romero, \& Turon, 2004), or the behavior of its growth rate (Sonnenholzner, Touron, \& Panchana-Orrala, 2018).

Mortality by predation in the early juvenile stages is considered the main bottleneck in echinoid populations (Tegner \& Dayton, 1981; McClanahan \& Muthiga, 1989; Sala, 1997; López et al., 1998). In this sense, the availability of refuge for juvenile sea urchins is a key factor in the rate of predation (Roberts \& Ormond, 1987; Hixon \& Beets, 1993), since hiding and protection in crevices becomes in the main strategy to avoid this predation.
In species like Echinometra mathaei, smaller individuals are more susceptible to predation than adults (Hart \& Chia, 1990). Himmelman (1988), suggests that the juveniles of Strongylocentrotus droebachiensis wait for refuges until reaching a certain size, after which they begin to move actively looking for food. Botsford, Smith, and Quinn (1994) indicate that the mortality rate increases when refuges from predators are limited. In species such as S. franciscanus and Echinometra vanbrunti, when they reach a certain size, they are forced to abandon their refuges, being more vulnerable to predation (Tegner \& Dayton, 1981; González-Peláez, 2004). In this regard, also has been reported that species such as $S$. purpuratus and $T$. depressus show cannibalistic behaviors of medium-sized individuals on small individuals in conditions of starving or low food availability, which could directly affect the presence of juveniles (Sonnenholzner, Montaño-Moctezuma, \& Searcy-Bernal, 2011; Sonnenholzner et al., 2018). However, in our study area there is a great food availability. The food availability of juvenile E. vanbrunti 
in Panama can be another limiting factor, so that spawning in populations occurs at the time of upwelling (Lessios, 1981).

Juveniles and adults can also present different distribution. For P. lividus migrations of small or medium-sized sea urchins have been described (Haya de la Sierra, 1990; Fernandez et al., 2001; Tomas et al., 2004), while the adults are more sedentary and capable of spending several months in confined spaces (Dance, 1987). However, there are reports that juvenile settlements in other species occur where adults live (Cameron \& Schroeter, 1980; Tegner \& Dayton, 1981).

Tropical species such as $T$. depressus, large-size, short time to maturity, fast growth rates, high reproductive effort, high respiration rates, high feeding capacity and short life span (Lawrence \& Agatsuma, 2013), present a low and highly variable survival rate of juveniles, which may be an adaptation of their life strategy (Stearns, 1976). In this sense, it has been reported that the proliferation densities of $T$. depressus in Ecuador can decrease rapidly or disappear completely at monthly intervals, contrary to slow-growing temperate species (Sonnenholzner et al., 2018), to which it contributes in largely the absence of juveniles.

For all these reasons, the low recruitment rate played a determining role in the distribution of the size structure found in $T$. depressus in this study.

The average test diameter in the study population was $9.79 \pm 0.03 \mathrm{~cm}$. This value is similar to that reported for this same species $(9.74 \pm 0.02 \mathrm{~cm})$ at Punta Arenas de la Ventana, Mexico (González-Peláez, 2001). In contrast, larger average test diameters were reported in two regions of the Galapagos Islands: 11.50 $\pm 0.08 \mathrm{~cm}$ (Luna, 2000) and the largest of $12.50 \mathrm{~cm}$ reported by Sonnenholzner, Moreira, and Panchana-Orrala (2019). The monthly frequency of test diameter in $T$. depressus showed a unimodal distribution, indicating that individuals could be of the same age, suggesting that this species reproduces massively. In this sense, Sonnenholzner et al. (2019) suggested that $T$. depressus presents an initial natural differentiation in the body size of small and large individuals of the same cohort.

The average body wet weight of $T$. depressus was $411.72 \pm 4.25 \mathrm{~g}$, higher than the figure reported $(347.6 \pm 4.31 \mathrm{~g})$ by González-Peláez (2001) for the same species. Individual body wet weight was highly variable and showed no discernible pattern. This may be due to various factors, including food availability, coelomic fluid, and gonadal weight, therefore these values have to be considered under this information. In this study, the total body weight was used for computing both the CI and the GI; in addition, gonad wet weight was also used for calculating the GI. Therefore, as discussed below, the GI values are implicitly biased given the dual nature of the gonad, and due to the allometric relationship between the gonad wet weight and the test diameter (Ebert et al., 2011). Thus, we found that neither IC nor GI are good indicators for the reproductive season in $T$. depressus. GWW and AGW were both better indicators of the reproductive status of the population, since no significant differences were found in the test length between months or sex studied (note that this could be different if the variation in the body size of the sample studied is more extensive).

Sea urchin gonads, unlike those of other organisms, also play a role as reserve organs regardless of sex. Nutritive phagocytes, present inside the gonad, store the nutrients necessary for initiating gametogenesis and supply them to germ cells (Walker, 1982; Walker et al., 2013; Unuma 2002; Unuma et al., 2015). Gonad wet weight is commonly used as an indicator of reproductive status. However, due to their dual role as nutrient reserve organs in sea urchins, gonads may show high weight values even in the intergametic stage due to the accumulation of nutrients in storage cells (Kenner \& Lares, 1991; Kelly, 2000; Unuma \& Walker, 2009). In $T$. depressus, GWW and AGW were significantly higher in males in our study. This pattern has also been reported for Abatus cavernosus from the Argentinian Patagonia (Gil, Zaixso, \& Tolosano, 2009). However, the opposite pattern (i.e., heavier gonads in females) has 
been reported for many other species such as S. droebachiensis (Meidel \& Scheibling, 1999), Holopneustes purpurascens (Williamson \& Steinberg, 2002), and Arbacia dufresnii (Epherra et al., 2015).

The lightest gonads in male and female T. depressus were found between January and March (winter), and the heaviest from April to September (spring-summer), although some high values were also observed from October to December. This trend was consistent with the pattern shown by gonad stages. In this sense, when gonads were heaviest, the frequency of individuals in growing stage was high. Growing stage presented the highest proportion of nutritive phagocytes. Additionally, in females there was high gonad wet weight during growing and mature stages (no significant different weights); this could not be appreciated in males because only one mature male was found. In this last female gonad stage, instead of nutritive phagocytes, the highest proportion of gametes provided the most weight. Therefore, gonad wet weight illustrates the dual nature of this organ in sea urchins. Once the reproductive cycle was understood, the GWW and AGW are useful to determine the reproductive season (spawning period) in sea urchins due to its timely development; i.e. spawning period is characterized by lower GWW an AGW, resulting from weight loss associated with gamete release, together with a low proportion of nutritive phagocytes.

We observed that spawning peaked from January to March (winter), with a smaller peak in August. This finding differs from previous studies on this same species. González-Peláez (2001) reported a single spawning period from May to August in Punta Arena, Bahía de La Ventana, BCS, Mexico. For this same locality, Álvarez-López (2017) reported that spawning occurred most of the year, except for December, although he described two major spawning seasons, one in October-November and the other from April to June. Meanwhile, the T. depressus population from the Galapagos Islands (Ecuador) shows two or three spawning periods per year. This is consistent with the fact that sea urchin species inhabiting in temperate zones exhibit a well-defined reproductive cycle, whereas tropical species show no apparent periodicity in spawning (Luna, 2000). Sonnenholzner et al. (2018) suggest that $T$. depressus has continuous, nondiscrete and synchronous gametogenic activity throughout the year, with two peaks of gonadal development for reproduction. This continuous reproduction pattern with peaks in winter and summer has been reported for other species of the genus such as $T$. ventricosus off the coast of Florida (McPherson, 1965) and T. gratilla in Madagascar, Kenya and the Philippines (Muthiga, 2005; Toha et al., 2017).

Populations of the same species often show differences in their spawning periods, and significant interannual differences may also occur within the same population (Pearse \& Cameron, 1991; Byrne, Andrew, Worthington, \& Brett, 1998). The lack of a well-defined spawning season seems to be common when food is highly available and environmental conditions are favorable (Kennedy \& Pearse, 1975; Pearse, Pearse, \& Davis, 1986; BaySchmith \& Pearse, 1987; Pearse \& Cameron, 1991; Guillou \& Michel, 1993). The partial release of gametes (different spawning periods) would ensure that at least part of the offspring would coincide with favorable environmental conditions (Calvo, Morriconi, \& Orler, 1998). Because of this characteristic, T. depressus has been considered as an opportunistic species that uses available resources to reproduce (Lawrence \& Agatsuma, 2013).

Gametic development is regulated by endogenous factors such as the nutritional state of the individual, which influences gonadal production (Meidel \& Scheibling, 1998; Walker \& Lesser, 1998; Garrido \& Barber, 2001), as well as by various environmental factors including photoperiod, light intensity, and temperature (Pearse et al., 1986; Bay-Schmith \& Pearse, 1987; McClintock \& Watts, 1990; Kelly, 2001; Mercier \& Hamel, 2009). Our results show that gonad wet weight in $T$. depressus was not correlated with temperature. Temperature functions as a trigger of reproductive events 
in many sea urchin species (James, Heath, \& Unwin, 2007). Many authors have reported that high temperatures could boost gonad development and maturation, and low temperatures, the onset of gametogenesis (Espinoza, Reyes, Himmelman, \& Lodeiros, 2008; GonzálezIrusta, 2009). Lara-Rueda (2004) found a positive correlation between temperature and the gonad cycle in E. vanbrunti. However, there is also evidence showing that gonad growth in P. lividus and S. droebachiensis is related to decreasing temperatures (Herrero-Barrencua, 2008; James \& Siikavuopio, 2012). Moreover, in species such as $S$. purpuratus no direct correlation was found between gonad cycle and temperature (Cochran \& Engelmann, 1975), similar to our findings for $T$. depressus in this study. Nevertheless, Gil (2015) concluded that, although temperature is not the key driving factor for the onset of gametogenesis or spawning in Pseudechinus magellanicus, it is essential for oocytes to reach their maximum development during the winter maturation.

Finally, the $T$. depressus gonad wet weight was significantly correlated with photoperiod, another factor known to influence the reproductive cycle. We found that gonad development (growing and premature stages) occurs in the months with the longest daylight periods, whereas spawning takes place during the season with the shortest daylight periods. Sea urchins can detect light intensity through their podia, which have innervated terminal discs containing photosensitive pigments (Lesser, Carleton, Böttger, Barry, \& Walker, 2011). Longer daylight periods have been found to be associated with the onset of gametogenesis in P. magellanicus and Evechinus chloroticus (Brewin, Lamare, Keogh, \& Mladenov, 2000; Gil, 2015). However, experimental studies on other species of sea urchins have shown that gametogenesis is restrained in long days and favored in short days (Pearse \& Cameron, 1991). Direct lighting and changes in day length are correlated with sea temperature in tropical shallow-waters, and both factors can affect sexual reproduction in marine invertebrates (Coma, Ribes, Gili, \& Zabala, 2000; Shpigel,
McBride, Marciano, \& Lupatsch, 2004; Farhadian, Yusoff, \& Arshad, 2014). This topic has yet to be investigated in $T$. depressus.

Gonad wet weight and adjusted gonad weight were found to be good indicators of the reproductive season of $T$. depressus. The lowest gonad wet weights were recorded in correspondence with the shortest daylight and the spawning peak (January and March).

Ethical statement: authors declare that they all agree with this publication and made significant contributions; that there is no conflict of interest of any kind; and that we followed all pertinent ethical and legal procedures and requirements. All financial sources are fully and clearly stated in the acknowledgments section. A signed document has been filed in the journal archives.

\section{ACKNOWLEDGMENTS}

This research was funded by Instituto Politécnico Nacional (SIP projets 20170262, 20195021, 20200693). Ailet Vives received a scholarship from Consejo Nacional de Ciencia y Tecnología; the results here presented are part of her thesis. Thanks to Sánchez-Salazar for the English translation.

\section{RESUMEN}

\section{Reproducción del erizo de mar Tripneustes depressus (Camarodonta: Toxopneustidae) en Bahía de La Paz, Baja California Sur, México}

Introducción: Las gónadas de erizo de mar (huevas o uni) se consideran un manjar culinario en todo el mundo. Sin embargo, solo unas pocas especies se consideran comestibles y se comercializan. El erizo de mar Tripneustes depressus ha generado el interés de productores de Baja California Sur, México, por la calidad de sus gónadas. Una base biológica es clave para diseñar una estrategia de manejo para $T$. depressus para considerar su explotación comercial. Objetivo: Determinar la época reproductiva de $T$. depressus a través de la descripción de los estadios de las gónadas y del ciclo reproductivo, y establecer su relación con factores ambientales. Métodos: Recolectamos muestras mensuales (octubre de 2016 a septiembre de 2017), registrando in-situ la temperatura y el fotoperiodo. Evaluamos una muestra de 1055 especímenes para las 
características demográficas, utilizando el peso total $(\mathrm{g})$ y el diámetro de testa $(\mathrm{cm})$. También hicimos el análisis histológico de las gónadas de 178 individuos. Resultados: El diámetro de la testa promedio fue de $9.70 \pm 0.03 \mathrm{~cm}$ $(5-12.50 \mathrm{~cm})$. Con base en la proporción en la gónada de células sexuales (gametos) y somáticas (fagocitos nutritivos), proponemos cinco estadios gonádicos (crecimiento, prematuro, maduro, desove e intergamético) para ambos sexos. Hubo dos épocas del año en que las gónadas eran más pesadas y se correspondían estrechamente con la etapa de crecimiento, coincidiendo con las proporciones más altas de fagocitos nutritivos. El desarrollo de las gónadas (etapas de crecimiento y prematuro) alcanza su punto máximo en los meses con los periodos de luz más largos, con desove en los periodos de luz más cortos. Conclusiones: El peso húmedo de las gónadas y el peso ajustado de las gónadas son buenos indicadores de la temporada reproductiva de $T$. depressus. Los pesos húmedos más bajos de las gónadas coincidieron con el pico de desove en el período con luz diurna más corto (enero y marzo).

Palabras clave: temporada reproductiva; pesos de gónadas ajustados; estadios gonadales; hueva de erizo; Echinoidea.

\section{REFERENCES}

Álvarez-López, I.K. (2017). Ciclo reproductivo de Tripneustes depressus (Agassiz, 1863) (Echinodermata: Echinoidea) en Punta Arena de la Ventana, Baja California Sur, México (Bachelor thesis). Universidad Autónoma de Baja California Sur, México.

Bay-Schmith, E., \& Pearse, J.S. (1987). Effect of fixed daylengths on the photoperiodic regulation of gametogenesis in the sea urchin Strongylocentrotus purpuratus. International Journal of Invertebrate Reproduction and Development, 11(3), 287-294.

Botsford, L.W., Smith, B.D., \& Quinn, J.F. (1994). Bimodality in size distributions: the red sea urchin Strongylocentrotus franciscanus as an example. Ecological Applications, 4(1), 42-50.

Brewin, P.E., Lamare, M.D., Keogh, J.A., \& Mladenov, P.V. (2000). Reproductive variability over a fouryear period in the sea urchin Evechinus chloroticus (Echinoidea: Echinodermata) from differing habitats in New Zealand. Marine Biology, 137(3), 543-557.

Byrne, M., Andrew, N.L., Worthington, D.G., \& Brett, P.A. (1998). Reproduction in the diadematoid sea urchin Centrostephanus rodgersii in contrasting habitats along the coast of New South Wales, Australia. Marine Biology, 132(2), 305-318.

Calvo, J., Morriconi, E., \& Orler, P.M (1998). Estrategias reproductivas de moluscos bivalvos y equinoideos. In E. Boschi (Ed.), El Mar Argentino y sus Recursos Pesqueros (pp. 195-231). Argentina: INIDEP, Mar del Plata.
Cameron, R.A., \& Schroeter, S.C. (1980). Sea urchin recruitment: effect of substrate selection on juvenile distribution. Marine Ecology Progress Series, 2(3), 243-247.

Cochran, R.C., \& Engelmann, F. (1975). Environmental regulation of the annual reproductive season of Strongylocentrotus purpuratus (Stimpson). The Biological Bulletin, 148(3), 393-401.

Coma, R., Ribes, M., Gili, J.M., \& Zabala, M. (2000). Seasonality in coastal benthic ecosystems. Trends in Ecology \& Evolution, 15(11), 448-453.

Dance, C. (1987). Patterns of activity of the sea urchin Paracentrotus lividus in the Bay of Port-Cros (Var, France, Mediterranean). Marine Ecology, 8(2), 131-142.

Ebert, T.A. (1967). Negative growth and longevity in the purple sea urchin Strongylocentrotus purpuratus (Stimpson). Science, 157(3788), 557-558.

Ebert, T.A., Hernandez, J.C., \& Russell, M.P. (2011). Problems of the gonad index and what can be done: analysis of the purple sea urchin Strongylocentrotus purpuratus. Marine Biology, 158(1), 47-58.

Epherra, L., Gil, D.G., Rubilar, T., Pérez-Gallo, S., Reartes, M.B., \& Tolosano J.A. (2015). Temporal and spatial differences in the reproductive biology of the sea urchin Arbacia dufresnii. Marine and Freshwater Research, 66, 329-342.

Espinoza, G., Reyes, J.L., Himmelman, J.H., \& Lodeiros, C. (2008). Echinometra lucunter (Echinodermata: Echinoidea) en relación con factores ambientales en el Golfo de Cariaco, Venezuela. Revista de Biología Marina, 56, 341-350.

Farhadian, O., Yusoff, Md, \& Arshad, A. (2014). Effects of salinity, temperature, light intensity and light regimes on production, growth and reproductive parameters of Apocyclops dengizicus. Iranian Journal of Fisheries Sciences, 13(1), 30-46.

Fernandez, C., \& Pergent, G. (1998). Effect of different formulated diets and rearing conditions on growth parameters in the sea urchin Paracentrotus lividus. Journal of Shellfish Research, 17, 1571-1581.

Fernandez, C., Caltagirone, A., \& Johnson, M. (2001). Demographic structure suggests migration of the sea urchin Paracentrotus lividus (Echinodermata: Echinoidea) in a coastal lagoon. Journal of Marine Biology Association of U.K., 81, 361-362.

Garrido, C.L., \& Barber, B.J. (2001). Effects of temperature and food ration on gonad growth and oogenesis of the green sea urchin, Strongylocentrotus droebachiensis. Marine Biology, 138(3), 447-456.

Gil, D.G., Zaixso, H.E., \& Tolosano, J.A. (2009). Brooding of the sub-Antarctic heart urchin, Abatus cavernosus 
(Spatangoida: Schizasteridae), in southern Patagonia. Marine Biology, 156, 1647-1657.

Gil, D.G. (2015). Biología y ecología del erizo de mar Pseudechinus magellanicus (Echinoidea: Temnopleuridae) en Patagonia Central (Doctoral thesis). Universidad Nacional de La Plata, Argentina.

González-Irusta, J.M. (2009). Contribución al conocimiento del erizo de mar Paracentrotus lividus (Lamarck, 1816) en el Mar Cantábrico: ciclo gonadal y dinámica de poblaciones. (Doctoral thesis). Universidad de Cantabria, España.

González-Peláez, S.S. (2001). Biología poblacional del erizo café Tripneustes depressus A. Agassiz, 1863 (Echinodermata: Echinoidea), en el sur del Golfo de California, México (Licenciature thesis). Universidad Autónoma de Baja California Sur, México.

González-Peláez, S.S. (2004). Biología poblacional del erizo Echinometra vanbrunti (Echinodermata; Echinoidea), en el Sur del Golfo de California, México (Master's thesis). Centro De Investigaciones Biológicas del Noroeste, México.

Guillou, M., \& Michel, C. (1993). Reproduction and growth of Sphaerechinus granularis (Echinodermata: Echinoidea) in Southern Brittany. Journal of the Marine Biological Association of the United Kingdom, 73(1), 179-192.

Harrold, C., \& Pearse, J.S. (1987). The ecological role of echinoderms in kelp forests. In H.M. Jangoux \& J.M. Lawrence (Eds.), Echinoderm studies (pp. 137-233). Rotterdam: Balkema Press.

Hart, L.J., \& Chia, F.S. (1990). Effect of food supply and body size on the foraging behavior of the burrowing sea urchin Echinometra mathaei (de Blainville). Journal of Experimental Marine Biology and Ecology, 135(2), 99-108.

Haya de la Sierra, D. (1989). Biología y ecología de Paracentrotus lividus en la zona intermareal. (Doctoral thesis). Universidad de Oviedo, España.

Herrero-Barrencua, A. (2008). Aspectos reproductivos del erizo común Paracentrotus lividus en aguas del Este de Gran Canaria (Bachelor thesis). Universidad de Las Palmas de Gran Canaria, España.

Himmelman, J.H. (1986). Population biology of green sea urchins on rocky barrens. Marine Ecology Progress Series, 33, 295-306.

Hixon, M.A., \& Beets, J.P. (1993). Predation, prey refuges, and the structure of coral-reef fish assemblages. Ecological Monographs, 63(1), 77-101.

Humason, G.L. (1979). Animal tissue techniques. San Francisco: W.H. Freeman and Company.
James, P., \& Siikavuopio, S.I. (2012). A guide to the sea urchin reproductive cycle and staging sea urchin gonad samples. Norway: Nofima.

James, P.J., Heath, P., \& Unwin, M.J. (2007). The effects of season, temperature and initial gonad condition on roe enhancement of the sea urchin Evechinus chloroticus. Aquaculture, 270, 115-131.

Kelly, M.S. (2000). The reproductive cycle of the sea urchin Psammechinus miliaris (Echinodermata: Echinoidea) in a Scottish sea loch. Journal of the Marine Biological Association of the United Kingdom, 80(5), 909-919.

Kelly, M.S. (2001). Environmental parameters controlling gametogenesis in the echinoid Psammechinus miliaris. Journal of Experimental Marine Biology and Ecology, 266(1), 67-80.

Kennedy, B., \& Pearse, J.S. (1975). Lunar synchronization of the monthly reproductive rhythm in the sea urchin Centrostephanus coronatus Verrill. Journal of Experimental Marine Biology and Ecology, 17(3), 323-331.

Kenner, M.C., \& Lares, M.T. (1991). Size at first reproduction of the sea urchin Strongylocentrotus purpuratus in a central California kelp forest. Marine Ecology Progress Series Oldendorf, 76(3), 303-306.

Lara-Rueda, G.N. (2004). Ciclo reproductivo del erizo de mar Echinometra vanbrunti (Agassiz 1863, Echinodermata, Echinoidea) en Ensenada de Muertos Baja California Sur México (Bachelor thesis). Universidad Autónoma de Baja California Sur, México.

Lawrence, J.M. (2007). The edible sea urchin. In J.M. Lawrence (Ed.), Edible sea urchins: Biology and Ecology. Netherlands: Elsevier Science.

Lawrence, J.M., \& Agatsuma, Y. (2013). Tripneustes. In J.M. Lawrence (Ed.), Sea urchins: Biology and Eco$\operatorname{logy}$ (Vol. 38, pp. 491-507). Elsevier.

Lesser, M.P., Carleton, K.L., Böttger, S.A., Barry, T.M., \& Walker, C.W. (2011). Sea urchin tube feet are photosensory organs that express a rhabdomeric-like opsin and PAX6. Proceedings of the Royal Society B: Biological Sciences, 278, 3371-3379.

Lessios, H.A. (1981). Reproductive periodicity of the echinoids Diadema and Echinometra on the two coasts of Panama. Journal of Experimental Marine Biology and Ecology, 50(1), 47-61.

López, S., Turon, X., Montero, E., Palacín, C., Duarte, C.M., \& Tarjuelo, I. (1998). Larval abundance, recruitment and early mortality in Paracentrotus lividus (Echinoidea). Interannual variability and plankton-benthos coupling. Marine Ecology Progress Series, 172, 239-251. 
Luna, S. (2000). Distribución poblacional y ciclo reproductivo del erizo de mar blanco Tripneustes depressus (Echinodermata: Echinoidea) en las Islas Galápagos (Bachelor thesis). Universidad San Francisco de Quito, Ecuador.

McBride, S.C., Pinnix, W.D., Lawrence, J.M., Lawrence, A.L., \& Mulligan, T.M. (1997). The effect of temperature on production of gonads by the sea urchin Strongylocentrotus franciscanus fed natural and prepared diets. Journal of the World Aquaculture Society, 28(4), 357-365.

McClanahan, T.R., \& Muthiga, N.A. (1989). Patterns of predation on a sea urchin, Echinometra mathaei (de Blainville), on Kenyan coral reefs. Journal of Experimental Marine Biology and Ecology, 126(1), 77-94.

McClintock, J.B., \& Watts, S.A. (1990). The effects of photoperiod on gametogenesis in the tropical sea urchin Eucidaris tribuloides (Lamarck) (Echinodermata: Echinoidea). Journal of Experimental Marine Biology and Ecology, 139(3), 175-184.

McPherson, B.F. (1965). Contributions to the biology of the sea urchin Tripneustes ventricosus. Bulletin of Marine Science, 15(1), 228-244.

Meidel, S.K., \& Scheibling, R.E. (1998). Annual reproductive cycle of the green sea urchin, Strongylocentrotus droebachiensis, in differing habitats in Nova Scotia, Canada. Marine Biology, 131(3), 461-478.

Meidel, S.K., \& Scheibling, R.E. (1999). Effects of food type and ration on reproductive maturation and growth of the sea urchin Strongylocentrotus droebachiensis. Marine Biology, 134(1), 155-166.

Mercier, A. \& Hamel, J.F. (2009). Endogenous and exogenous control of gametogenesis and spawning in echinoderms. Londres: Academic Press.

Montealegre, S.Q., \& Gómez, A.G. (2005). Ciclo reproductivo de Lytechinus variegatus (Echinoidea: Toxopneustidae) en el sur de Isla Margarita, Venezuela. Revista de Biología Tropical, 53, 305-312.

Muthiga, N.A. (2005). Testing for the effects of seasonal and lunar periodicity on the reproduction of the edible sea urchin Tripneustes gratilla (L) in Kenyan coral reef lagoons. Hydrobiologia, 549(1), 57-64.

Packard, G.C., \& Boardman, T.J. (1999). The use of percentages and size specific indices to normalize physiological data for variation in body size: wasted time, wasted effort?. Comparative Biochemistry and Physiology Part A, 122, 37-44.

Pearse, J.S., Pearse, V.B., \& Davis, K.K. (1986). Photoperiodic regulation of gametogenesis and growth in the sea urchin Strongylocentrotus purpuratus. Journal of Experimental Zoology, 237(1), 107-118.
Pearse, J.S., \& Cameron, R.A. (1991). Reproduction of marine invertebrates. In A.C. Giese, J.S. Pearse, \& V.B. Pearse (Eds.), Echinodermata: Echinoidea. Echinoderms and Lophophorates (Vol 6, pp. 514-662). California: The Boxwood Press, Pacific Groove.

Ridder, J., \& Lawrence, M. (1982). Food and feeding mechanisms: Echinoidea. In M. Jangoux \& J.M. Lawrence (Eds.), Echinoderm nutrition (pp. 331372). Rotterdam, Netherland: Balkema.

Roberts, C.M \& Ormond, R.F.G. (1987). Habitat complexity and coral reef fish diversity and abundance on red sea fringing reefs. Marine Ecology Progress Series, 41, 1-8.

Sala, E. (1997). Fish predators and scavengers of the sea urchin Paracentrotus lividus in protected areas of the north-west Mediterranean Sea. Marine Biology, 129(3), 531-539.

Sala, E., \& Zabala, M. (1996). Fish predation and the structure of the sea urchin Paracentrotus lividus populations in the NW Mediterranean. Marine Ecology Progress Series, 140, 71-81.

Sánchez-España, A., Martínez-Pita, I., \& García, F.J. (2004). Gonadal growth and reproduction in the commercial sea urchin Paracentrotus lividus (Lamarck, 1816) (Echinodermata: Echinoidea) from southern Spain. Hydrobiologia, 519(1-3), 61-72.

Shpigel, M., McBride, S.C., Marciano, S., \& Lupatsch, I. (2004). The effect of photoperiod and temperature on the reproduction of European sea urchin Paracentrotus lividus. Aquaculture, 232(1-4), 343-355.

Sokal, R.R., \& Rohlf, F.J. (1979). Biometría: Principios y métodos estadísticos en la investigación biológica. Madrid: H. Blume.

Sonnenholzner, J.I., Montaño-Moctezuma, G., \& SearcyBernal, R. (2011). Effect of macrophyte diet and initial size on the survival and somatic growth of sub-adult Strogylocentrotus purpuratus: a laboratory experimental approach. Journal of Applied Phycology, 23, 505-513.

Sonnenholzner, J.I., Touron, N., \& PanchanaOrrala, M.M. (2018). Breeding, larval development, and growth of juveniles of the edible sea urchin Tripneustes depressus: a new target species for aquaculture in Ecuador. Aquaculture, 496, 134-145.

Sonnenholzner, J.I., Moreira, J.A., \& Panchana-Orrala, M.M. (2019). Growth performance and survival of Holothuria theeli (holothurian) fed with feces of Tripneustes depressus (echinoid): A multi-trophic aquaculture approach. Aquaculture, 512, Article number 734345 . 
Spirlet, C., Grosjean, P., \& Jangoux, M. (2000). Optimization of gonad growth by manipulation of temperature and photoperiod in cultivated sea urchins, Paracentrotus lividus (Lamarck) (Echinodermata). Aquaculture, 185(1-2), 85-99.

Stearns, S.C. (1976). Life-history tactics: a review of the ideas. The Quarterly Review of Biology, 51(1), 3-47.

Tegner, M.J., \& Dayton, P.K. (1981). Population structure, recruitment and mortality of two sea urchins (Strongylocentrotus franciscanus and S. purpuratus) in a kelp forest. Marine Ecology Progress Series, 5, 255-268.

Timeanddate. (2017). Retrieved 18 October 2017, from https://www.timeanddate.com/sun.

Toha, A.H.A., Sumitro, S.B., Hakim, L., Widodo, N., Binur, R., Suhaemi, S., \& Anggoro, A.W. (2017). Biology of the commercially used sea urchin Tripneustes gratilla (Linnaeus, 1758) (Echinoidea: Echinodermata). Ocean Life, 1(1), 1-10.

Tomas, F., Romero, J., \& Turon, X. (2004). Settlement and recruitment of the sea urchin Paracentrotus lividus in two contrasting habitats in the Mediterranean. Marine Ecology Progress Series, 282, 173-184.

Toro-Farmer, G., Cantera, J.R., Londono-Cruz, E., Orozco, C., \& Neira, R. (2004). Patrones de distribución y tasas de bioerosión del erizo Centrostephanus coronatus (Diadematoida: Diadematidae), en el arrecife de Playa Blanca, Pacífico colombiano. Revista de Biología Tropical, 52(1), 67-76.

Unuma, T. (2002). Gonadal growth and its relationship to aquaculture in sea urchins. In Y. Yokota, V. Matranga, \& Z. Smolenicka (Eds.), The Sea Urchin: From Basic Biology to Aquaculture (pp. 115-127). Lisse: Swets \& Zeitlinger.

Unuma, T., \& Walker, C.W. (2009). Relationship between gametogenesis and food quality in sea urchin gonads. In R. Stickney, R. Iwamoto, \& M. Rust (Eds.), Aquaculture Technologies for Invertebrates: Proceedings of the 36th US-Japan Aquaculture Panel Symposium (pp. 45-53). Durham, New Hampshire and Milford, Connecticut: NOAA Technical Memoires.

Unuma, T., Murata, Y., Hasegawa, N., Sawaguchi, S., \& Takahashi, K. (2015). Improving the food quality of sea urchins collected from barren grounds by short-term aquaculture under controlled temperature. Bulletin of Fisheries Research Agency, 40, 145-153.

Vaitilingon, D., Rasolofonirina, R., \& Jangoux, M. (2005). Reproductive Cycle of Edible Echinoderms Tripneustes gratilla (Echinoidea, Echinodermatata) from the Southwestern Indian Ocean. Western Indian Ocean Journal of Marine Science, 4(1), 47-60.

Vives, A. (2018). Calidad de la gónada del erizo de mar Tripneustes depressus (Agassiz, 1863) (Echinodermata: Echinoidea) en la Bahía de La Paz, Baja California Sur, México (Master's thesis). Instituto Politécnico Nacional, México.

Walker, C.W. (1982). Nutrition of gametes. In M. Jangoux \& J. Lawrence (Eds.), Nutrition of Echinoderms (pp. 449-468). Rotterdam: Balkema.

Walker, C.W., \& Lesser, M.P. (1998). Manipulation of food and photoperiod promotes out-of-season gametogenesis in the green sea urchin, Strongylocentrotus droebachiensis: implications for aquaculture. Marine Biology, 132(4), 663-676.

Walker, C.W., Unuma, T., \& Lesser, M.P. (2007). Gametogenesis and reproduction of sea urchins. In J.M. Lawrence (Ed.), Developments in Aquaculture and Fisheries Science (Vol. 37, pp. 11-33). Amsterdam: Elsevier.

Walker, C.W., Lesser, M.P., \& Unuma, T. (2013). Sea urchin gametogenesis-structural, functional and molecular/genomic biology. In J.M. Lawrence (Ed.), Sea urchins: Biology and Ecology, (Vol. 38, pp. 25-43). Amsterdam, Netherlands: Elsevier.

Williamson, J., \& Steinberg, P. (2002). Reproductive cycle of the sea urchin Holopneustes purpurascens (Temnopleuridae: Echinodermata). Marine Biology, 140(3), 519-532. 